DOI 10.14746/ssp.2014.1.2

Stanisław WÓJCIK

Katolicki Uniwersytet Lubelski Jana Pawła II

\title{
Ubóstwo i bogactwo w Polsce na początku XXI wieku. Ocena neoliberalizmu z punktu widzenia katolickiej nauki społecznej
}

25 lat trwająca w Polsce transformacja ustroju politycznego i gosposię ubóstwa, wyjazdów za granicę polskiej młodzieży w poszukiwaniu pracy oraz pojawieniem się grupy oligarchów - ludzi superbogatych. Wyjaśnienia, diagnozy tej sytuacji, jakie udziela sobie opinia publiczna, zwykli ludzie, publicyści, pisarze polityczni, nierzadko ludzie nauki, ekonomiści, prawnicy, politolodzy i filozofowie są często emocjonalne, niekiedy i bezradne, stąd pojawiają się na nowo pytania: w czyich rękach znalazło się bogactwo, jak do tego doszło, jaki naprawdę jest ten świat ekonomii, biznesu i polityki, jak się przygotować, aby stawić czoła nowym wyzwaniom, jak odmienić swój los.

Ubóstwo i bogactwo nie występują w izolacji, lecz w relacji do stanu gospodarki kraju, dominującej ideologii, ustroju politycznego, kultury, nauki. Warto zająć się tymi działami w relacji do bogactwa i ubóstwa. Dlaczego obecnie? Bo zaszły potężne zmiany, bo wciąż powstają olbrzymie problemy. Obecne ubóstwo i bogactwo w Polsce jest kontynuacją sytuacji z przełomu XX i XXI wieku. Łączy się z istniejącymi teoriami, doktrynami, jak i faktyczną realizacją transformacji. Nastapił przełom. Upadł socjalizm, a rozwija się neoliberalny w warunkach Polski, dziki kapitalizm. Jego główną cechąjest wiara w nieskrępowane działanie konkurencji rynkowej, że rynek jest mechanizmem samoregulującym. Kapitalizm ten ogranicza do minimum własność publiczna, centralny budżet państwa, opiekę społeczna, związki zawodowe. Polityka zatrudnienia nie jest głównym celem polityki gospodarczej. W efekcie powoduje powstanie wielkich nierówności materialnych, fragmentaryzację społeczeństwa i absolutne ubóstwo wielkiej rzeszy ludzi. Ten kapitalizm stawiany jest przed człowiekiem.

Obecna polska gospodarka jest oparta na zasadach skrajnej ideologii liberalnej. Oznacza to, że działa ona nie według praw społecznych, lecz 
według praw przyrodniczych, tj. bezwzględnie, przy stale zmniejszającej się interwencji ze strony państwa. Spowodowało to powstanie niewielkiej grupy oligarchów i olbrzymiej sfery ludzi zubożonych. Klasa polityczna zarówno postsolidarnościowa, jak i postkomunistyczna nie przeszkadzają temu jednostronnemu bogaceniu się. Zahamowanie procesu narastającego ubóstwa sprowadzają do postulatów zobowiązania bogatych do większego świadczenia na rzecz biednych bez zmiany tworzącej się struktury społecznej o silnych biegunach bogactwa i biedy. Nie powstały jeszcze znaczące ruchy społeczne, które domagałyby się, aby państwo efektywnie oddziaływało na wolny rynek.

Poszukiwanie przyczyn niesprawiedliwości społecznej zrodziło różne odmiany socjalizmu, marksizm, keynesizm. Zagadnienia gospodarcze podjęła również katolicka nauka społeczna, formułując zasady społecznej gospodarki rynkowej funkcjonującej i dynamicznie rozwijającej się np. w Niemczech. Powstały nowe teorie ekonomiczne coraz wszechstronniej naświetlające przyczyny zakłóceń, asynchronię faz rozwoju gospodarczego, jak i poszukujące możliwości zespolenia wolności gospodarowania, ze sprawiedliwością społeczną wskazujące na możliwości osiągnięcia zadowolenia społecznego.

Własność kapitału ma tendencję do zbytniej koncentracji. Przeciwdziałanie dyktatowi kapitału i wyzyskowi leży we właściwym ustawodawstwie i prawidłowym używaniu rządowych regulacji, mających na celu zredukowanie koncentracji i nieustanne rozszerzenie zakresu prywatnej własności środków produkcji. Korzyści, jak i sukcesy kapitalizmu, rosną proporcjonalnie do liczby ludzi będących kapitalistami. Bogactwo nowych oligarchów nie przekłada się na bogactwo świata pracy.

Żyjemy w czasach osłabienia znaczenia państwa i nie mamy gotowego modelu, jakie ono powinno być. Według liberałów odgrzewających starą koncepcję - nie przystającą do Polski wskutek jej położenia geopolitycznego - instytucja państwa jest wrogiem wolności, bo stosuje przymus, zniewala, bo nie liczy się z jednostką i jej światem. Z kolei postkomuniści widzą w państwie tzw. oświecone centrum, omnipotencję kontrolującą wszystko i wszystkich. I jedni i drudzy mówią przy tym, że należy zapomnieć o państwie opiekuńczym i sprawiedliwym. W rezultacie bardzo mało, prawie nic, nie pisze się o państwie jako instytucji pomocniczej, zgodnie z koncepcją formowaną na gruncie katolickiej nauki społecznej oraz doktryny personalizmu społecznego.

Społeczeństwo, w tym wielu polityków i ekonomistów, jest zdezorientowane, jeśli chodzi o wybór kierunku rozwoju gospodarczego, o wypra- 
cowanie polityki gospodarczej i społecznej. Główny problem polega na tym czy mamy stawiać na prywatyzację bez „dobra wspólnego”? Obecnie likwiduje się majątek państwa, powstają monopole własności grupowej i jednostkowej (przed którymi bardzo przestrzegał A. Smith). Do rangi ideału została wyniesiona absolutna prywatyzacja, w efekcie przestano pisać o dobru wspólnym dla wszystkich obywateli.

Także wolny rynek- patrząc na dzisiejszą rzeczywistość - jest wolny od wszelkich norm społecznych, prawnych i moralnych (co znowu jest w niezgodzie z poglądami A. Smitha, który dowodził, że gospodarka rynkowa wnosi postęp społeczny i moralny, a nie tylko ekonomiczny). Sytuacja dzisiejsza przypomina obaloną przez życie tezę marksistowską, że ekonomia jest bazą i regulatorem wszystkich dziedzin życia, jest to wciąż wąski ekonomizm, nieprzystający do żadnej antropologii klasycznej. Doktryna liberalna wnosi wiele rozwiązań pożytecznych, ale chodzi o jej dzisiejszą ewolucję po Maastricht I i II. Jej duch ogólny jest drapieżny, antychrześcijański i kolonizatorski.

W tych warunkach, jak zauważa Czesław Bartnik, pracodawca i robotnik, stają się dla siebie wrogami, chociaż wydawało się, że po historycznych doświadczeniach wyciągnięto właściwe wnioski. Przyznają to sami ideologowie zachodni, którzy bez ogródek stwierdzają, że mała własność dla zwykłych robotników jest tylko źródłem ich deprawacji, rozleniwienia, przestępczości, że związki zawodowe są niepotrzebne, bo krępują śmiałe inicjatywy menedżerów, hamują rozwój gospodarczy, szerzą nieprawdziwe poglądy o równości społecznej, że w ogóle świat robotniczy i chłopski jest prymitywny i rozpuszczony przez dawne ideologie i powinien być wychowywany przez ciężką pracę, bezrobocie, niedopuszczony do wyższego wykształcenia i stanowisk, skąd, jak sądzę, bierze się obecna liberalna antykulturalna polityka naszych władz, przyznawania coraz mniejszych sum z budżetu na rozwój oświaty, służby zdrowia, kultury. Można domniemywać, że cele i konsekwencje tego będą takie, że masy pracownicze, których nie da się zagospodarować, będą musiały wymierać - stąd aborcja, eutanazja, osłabienie służby zdrowia, szerzenie plag wyniszczających ludność. Jednocześnie masy te są zabawiane obrazkami TV, pornografią, sportem, powszechną prostytucją żeńską i męską, konfliktami wewnątrzrodzinnymi, uzależnieniami, loteriami, nie karanymi rozbojami, terroryzmem, obchodami rocznic i świąt, folklorem, nic niedającymi głosowaniami, obietnicami na przyszłość i opowiadaniami bajek o raju europejskim. Towarzyszy temu wiara liberałów w moc anonimowego prawa, stanowionego przez elity ekonomiczno-polityczne, które 
jako drugi filar rynku, ma zastapić struktury państwa, autorytety, a nawet Kościół oraz we wszechwładzę pieniądza jako esencji życia, uniwersalnej energii (Bartnik 2012, s. 114 i n.; por. tenże, 2009, s. 12-19 i 250-257).

Piotr Jaroszyński uważa, że wiele wskazuje na to, iż bogactwo przeszło w ręce globalnej oligarchii, czyli małego grona najbogatszych ludzi, dla których przynależność państwowa, narodowa lub religijna nie ma żadnego znaczenia (Jaroszyński, 2011, s. 16). Zdaniem Charlesa Derbera światem rządzą wielkie korporacje i ich ludzie. To oni decydują o posunięciach rządów i w USA, i w Polsce. Podział na lewicę i prawicę, liberałów i etatystów, to przeżytek. Rządy i politycy nie są już kontrolowani przez obywateli jako suwerena. Coraz częściej mamy demokratyczne procedury, jak wolne wybory, ale niekoniecznie mamy wpływ obywateli na władzę. W takich sprawach jak opieka zdrowotna, regulacja gospodarki, stosunek do podatków i płac, energetyki mamy przepaść. Rządy działają $\mathrm{w}$ interesie prawdziwego suwerena, takiego rządu za kurtyną. W USA ten realny rząd tworzą największe korporacje pakujące gigantyczne kwoty w każdy cykl wyborczy. Zamiast demokracji mamy więc korpokrację. Priorytetem jest zawsze interes wielkiego biznesu (Derber, 2011, s. 4).

Z innych analiz ekonomistów i socjologów, którzy opisują obecny stan gospodarki świata wynika, że na naszych oczach dokonuje się wyjście ekonomii z fazy postindustrialnej w tzw. finansjeryzację. Proces ten doprowadził już do wyłonienia się klasy superbogatych. Jest to całkiem liczna rzesza menedżerów, spekulantów i beneficjentów skarbu państwa, którzy działają na styku polityki i biznesu. Tej kategorii nie należy mylić z przedsiębiorcami, którzy na ogół ryzykują więcej i zarabiają mniej od superbogaczy. To, czego jesteśmy świadkami w ostatnich dekadach, to ucisk biedaków i klasy średniej przez klasę bogaczy. Podnoszą oni cenę wielu dóbr, podatki, procenty od kredytów, powodując rosnącą spiralę zadłużenia, utratę oszczędności, prowadząc spekulacje finansowe i doprowadzili do światowego kryzysu ekonomicznego. Rządy zachodnie ratują wielkie banki i instytucje państwowe, ładują bez końca pieniądze $\mathrm{w}$ ich ratowanie, podnoszą podatki, z którymi klasa robotników, jak i przedsiębiorcy prywatni nie mogą sobie poradzić. Nie przynosi to żadnych korzyści zdecydowanej większości obywateli. Stają się oni, wbrew obietnicom, coraz biedniejsi. W efekcie kryzys trwa. Nie wyjdziemy z niego tak długo, jak długo będziemy pozostawać w błędnym kole prymatu ekonomii. Mamy bowiem do czynienia również z kryzysem doktrynalnym i kulturowym (Gallino za: Introvigne, 2012, s. 14). 
Dla wielu ludzi świat ekonomii i biznesu jest tajemniczy, a nawet moralnie brudny, to świat ciemnych interesów, wielkich przekrętów, gdzie jednych nie obowiązują żadne zasady moralne i reguły prawne, inni zaś uczestnicy rynku są ścigani za najmniejsze przekroczenia. P. Jaroszyński zwraca uwagę, że z dala od wielkiego biznesu znajduje się większość katolików, którzy nie chcą się „brudzić moralnie”, bo nie mają głowy do interesów, a przecież działalność gospodarcza nie musi być brudna czy trudna. Jako argument przytacza opinię Maxa Webera z książki Etyka protestancka a duch kapitalizmu (1905 r.), gdzie autor dowodził, że gwałtowny rozwój przedsiębiorczości w czasach nowożytnych i współczesnych zawdzięczać należy religii i etyce protestanckiej, które wytworzyły tę potężną siłę, za którą stoi duch kapitalizmu. To poważne racje religijne, jak np. że religia dyscyplinuje wewnętrznie człowieka, uwrażliwia na kwestie społeczne, rozwija cnotę oszczędzania sprawiły, że nie byłoby kapitalizmu bez tak mocnego zaangażowania się w biznes. Jednak z biegiem czasu protestantyzm uległ sekularyzacji, przekształcił się następnie w liberalizm ateistyczny, jeszcze bardziej absolutyzujący znaczenie ekonomii, który z czasem podjął rywalizację z komunizmem sowieckim i chińskim. Oba komunizmy pod koniec XX wieku wyrodziły się w kapitalizm państwowy, a wówczas ich walka zamieniła się we współpracę, z której dzisiaj korzystają globalni oligarchowie. Także katolicyzm docenia ekonomię jako środek do osiągnięcia bogactwa, ale nie przecenia, nie uznaje za cel sam w sobie. Tym celem jest tu zawsze rozwój duchowy, moralny i kulturalny człowieka, a nie mnożenie bogactwa (Jaroszyński, 2011, s. 16). Jest ono celem państwa w wymiarze służenia społeczeństwu.

Nad rozwiązaniem problemu optymalnej organizacji życia gospodarczego i politycznego wciąż zastanawia się wielu ludzi - ekonomiści i politycy. Można chyba podzielić stanowisko Josepha Vogla, że obecnie toczy się walka o to, kto i gdzie podejmować może suwerenne decyzje. To jest nowa odsłona problemu suwerenności ekonomicznej: istotne decyzje gospodarcze i z zakresu polityki społecznej dyktowane są nie przez wybrane demokratycznie rządy, lecz rynki i działających na nich graczy. Dla Vogla zmiana obecnego modelu gospodarki wolnorynkowej jest możliwa pod warunkiem zredukowania władzy rynku oraz określenia i zmiany tych zasad wolnej konkurencji, które nie służą społeczeństwu, są wręcz źródłem traumy (Vogl, 2011, s. 18).

Problemem kapitalizmu jest wolny rynek. Jego skutki odczuwają wszystkie społeczeństwa. W Polsce partie rządzące i opozycyjne przyjęły odmienne założenia ustroju rynkowego. Spowodowało to rozbicie opinii 
publicznej, podzieleni są pisarze polityczni, publicyści, a nawet ludzie nauki. Większość z nich popiera rząd, są oni za wspólną polityką europejską. Tylko nieliczni zwolennicy solidaryzmu są przeciwko polityce skrajnie liberalnej. Konrad Kołodziejski dowodzi, że zwolennicy gospodarki opartej na liberalizmie (PO) doprowadzili do spacyfikowania społeczeństwa, do wypromowania modelu Polaka, jako bezwolnego konsumenta cudzych idei i dóbr, słabego i niezdolnego do krytycznej oceny rzeczywistości (Kołodziejski, 2013, s. A10). Z kolei Jerzy Żyżyński, pisząc o programie polityki gospodarczej PiS, wskazuje na dostrzeżone tam kierunki naprawy gospodarki polskiej, na zmiany w polityce fiskalnej i pieniężnej rządu (Żyżyński, 2013, s. A10).

W ostatnim czasie (2013/2014) pod pręgierz krytyki dostał się koalicyjny rząd PO-PSL. Ma ona charakter frontalnego ataku społeczeństwa i pewnej części publicystów, którzy zarzucają rządowi brak pomysłów na ożywienie i rozwój gospodarki. Pisarze polityczni domagają się rozwiązań, jak prowadzić reindustrializację, programów walki z bezrobociem, polityki prorodzinnej, że rząd nie ma pomysłu na wzrost płac, a rosną podatki i ceny. Niepokoi wysokie zadłużenie państwa, trudna sytuacja rolników, służby zdrowia, oświaty, krytykowany jest parlament, wymiar sprawiedliwości, coraz bardziej arogancka biurokracja.

Dyskusje toczą się o to, w jakich dziedzinach przemysłu Polska może zaistnieć, że musi rozwinąć własną gospodarkę, której wytwórczość jest obecnie ograniczona do minimum. Pozytywnie oceniany jest handel i usługi finansowe. Duże nadzieje wiązane są z eksploatacją przemysłu łupkowego. Tu jednak rząd wykazuje się brakiem konsekwentnego działania, stosuje jakieś niezrozumiałe uniki, nie wyjaśnia zadowalająco problemów, co może narazić Polskę na wielkie straty. Tymczasem innowacyjność i postęp techniczny jest możliwy, gdy rozwijany jest przemysł. W Polsce firmy przemysłowe były dotąd wykupywane i najczęściej likwidowane, bo obcym inwestorom chodziło o kupno polskiego rynku. Tak zniszczony został przemysł stoczniowy, huty, przemysł samochodowy, przemysły kooperujące, co doprowadziło, że obecnie mamy jedynie enklawy gospodarki.

Rząd Polski bardzo liczy na pomoc ekonomiczną i polityczną z UE, a zwłaszcza rządów Niemiec i Francji. Ale jak się wydaje mniej zwraca uwagi na pułapki z niej wynikające, jak chociażby ogłaszany przez rząd wzrost gospodarczy, który nie przekłada się na poprawę życia ludzi, na wzrost płac, niewiele też poprawiają się wskaźniki bezrobocia, gdyż wielkie zyski (ok. 70 mld zł rocznie) firmy zagraniczne wywożą do swoich 
krajów. Także dofinansowanie z Unii Europejskiej, cenne dla naszej gospodarki jednocześnie, wydatnie przyczynia się do zadłużenia państwa (nasz 30\% wkład do dotacji UE pochodzi często z pożyczek).

We władzach państwa dominują rzecznicy krańcowej wersji doktryny liberalnej. Uznają oni rynek za najważniejszy, jedynie racjonalny i obiektywny stymulator rozwoju produkcji i usług, widząc w nim główną siłę napędową rozwoju każdej gospodarki i społeczeństwa. Uważają oni, że zarówno w ekonomii, jak i polityce, decydować powinna konkurencja, w wyniku której każdorazowo wyłoni się większość parlamentarna, a przy tym najbardziej rozwiniętą podmiotowość (ekonomiczną i polityczną) będą mieć oligarchowie pieniądza. Z kolei wśród wartości naczelnymi są: bogacenie się, egoistyczny racjonalizm, rywalizacja, dominacja. Inne wartości, jak praca, wykształcenie, solidarność, pomocniczość nie mają dla nich większego znaczenia, ale uznają je, bo muszą, z obawy przed buntem społecznym.

Wyraźnie odmienne stanowisko zajmuje opozycja z PiS nawiązująca do szkoły ekonomii społecznej (Niemcy, Szwecja, Francja, USA i in.). Opowiadając się za wolnym rynkiem chcą na niego oddziaływać szeregiem stymulatorów. Chcą ograniczenia drapieżności konkurencji, obszarów nędzy, domagają się progresji podatkowej dla najbogatszych, krytykują filantropię bogatych, są rzecznikami określonego prawnie interwencjonizmu i mecenatu państwa. Opowiadają się za rzeczywistą podmiotowością ekonomiczną i społeczno-polityczną społeczeństwa. Podkreślają stymulującą rolę polityki - państwa, aby ustawodawca przez dobre prawo finansowe tworzył tamę do powstawania w naszym kraju wąskiej grupy oligarchów pieniądza. Nie można zamienić oligarchii politycznej na ekonomiczną, bo na dłuższą metę prowadzić to będzie do alienacji jednych i rewolucyjnej emancypacji drugich, czyli do wyniszczania narodu i państwa. Państwo powinno być zorientowane narodowo i socjalnie.

Zasadność ingerowania państwa, jako arbitra w system rynkowy wynika z konieczności realizowania dobra wspólnego, interesów całości społeczeństwa, bogatych i biednych. Współcześnie nie ma kraju, w którym nie stosowałoby się interwencji państwowej. Gospodarka taka jest konieczna w zakresie istniejących rodzajów własności. Także rolnictwo, handel międzynarodowy są dziedzinami, które wymagają interwencji gospodarczej państwa. Nadto zarządzanie jest konieczne w sferze ochrony środowiska naturalnego. Państwo musi mieć prawo np. zamykania trujących zakładów, winno wymuszać w tym zakresie obligatoryjne inwestycje. 
Ważnym czynnikiem bogactwa i ubóstwa jest nauka i wychowanie społeczne. Wychowanie to musi mieć swój program ogólnoludzki. Jest tu ważne, jakie wybrać kształcenie i wychowanie. Związek nauki z polityką i ekonomią ma współcześnie kluczowe znaczenie dla wyjaśnienia zakresu i głębi aktualnych zjawisk o charakterze wychowawczym, zwłaszcza że tradycyjne paradygmaty interpretacyjne ujawniają swoją bezradność. Rozważania dotyczące istnienia zależności między wychowaniem i nauką a szeroko rozumianą ekonomią pojawiały się już wcześniej w filozofii, to jednak współczesna analiza tego związku przybiera szerszy kierunek rozważań. Współczesna dominacja ekonomii, a szczególnie wolnego rynku sprawia, iż rynkowe stają się wszelkie zachowania jednostkowe, grupowe i społeczne.

Odnośnie systemu oświatowo-wychowawczego rządząca koalicja PO-PSL realizuje de facto wycofywanie się państwa nie tylko z mecenatu kultury, ale także z zadań wychowawczych, oświatowych, ideowych, twórczych i w ogóle wyższych. Przy tym uznaje, że społeczeństwo winno się „samokształtować”, a zarazem zakłada orientację na zasadnicze zróżnicowanie edukacji, tj. dla większości państwowy system kształcenia, który przygotowywałby tanią siłę roboczą, a dla bogatych tworzenie elitarnych systemów kształcenia zależnych od statusu materialnego. Podstawą budowy tego systemu (indywidualizm) mają być potrzeby jednostki ludzkiej nie zaś potrzeby społeczne. Ma tu miejsce również potępienie wszelkiej manipulacji w procesie kształcenia i wychowania, ale ma ona charakter formalny, o czym przekonuje faktyczna realizacja budowy nierównoprawnych i nierównowartościowych ciagów kształcenia.

Liberałowie proponują ideał wychowawczy, który polega na odejściu od wzoru Polaka zaściankowego romantyka na pozycję jednostki nowoczesnej, obywatela Europy i świata. Jednak wykształcenie traktują jako wartość instrumentalną wobec pieniądza. Liczyć się mają wyłącznie sukcesy ekonomiczne, prymat celów jednostkowych nad zbiorowymi oraz obojętność wobec innych systemów wartości i filozofii.

W zakresie systemu oświatowo-wychowawczego opozycja (PiS) opowiada się również za wielością ciagów kształcenia, ale jednocześnie za dążeniem do ich równowartości. Uważają, że selekcja w oświacie powinna pełnić rolę wtórną i dotyczyć właściwości jednostki, a nie jej materialnego położenia. Ich ideał wychowawczy Polaka to jego otwarcie na Europę i świat, odchodzenie od zachowań nacjonalistycznych, ale jednocześnie przy zachowaniu identyfikacji z własnym narodem. Wykształcenie jest tu ujmowane jako druga wartość po pracy. Podzielam pogląd, aby 
ideał ten dawał Polakowi realne szanse wyboru odpowiedniego kształcenia pod kątem swoich zdolności, by w efekcie miał dostęp do wysokokwalifikowanej pracy i do podmiotowego usytuowania w życiu społeczno-politycznym i w kulturze, umiał się bronić, był przygotowany do obrony swego państwa przed jego alienacją.

Hałaśliwa propaganda liberalizmu, która usiłuje zagospodarować społeczny teren dla siebie, w sytuacji 4-5 milionowego bezrobocia w Polsce, gubi z pola widzenia odpowiedzialność za ubogich, za patologię społeczną. Na fakt ten zwrócił uwagę Jan Paweł II, przywołując ideę państwa prospołecznego $\mathrm{W}$ sensie religijnym. W czasie pielgrzymki w Polsce (2002 r.), stwierdził: „Bez miłosierdzia życie społeczne nie ma korzeni ani sensu". W ten sposób papież podkreślił znaczenie - dla prawidłowego rozwoju zintegrowanego społeczeństwa - jedności, zgody i braterskiej solidarności. Dlatego ten chaotyczny dzisiaj etap rozwoju liberalizmu należy poddać korekcie przez uwzględnienie społecznego i etyczno-prawnego punktu widzenia. Nie wystarczy bowiem dać ludziom szansę, ale trzeba im pomóc ją wykorzystać.

\section{Bibliografia}

Bartnik C. S. (2009), Trud i czar myśli, Lublin.

Bartnik C. S. (2012), Siódma pieczęć, Lublin.

Derber Ch. (2011), Spiski to pót biedy przy korporacji, „Super Express”, 27 IX 2011, s. 4-5.

Introvigne M. (2012), Odczytać kryzys, „Nasz Dziennik”, 16-17 VI 2012, s. 14-15.

Jaroszyński P. (2011), Ku ekonomii katolickiej, „Nasz Dziennik”, 29-30 X 2011, s. 16.

Kołodziejski K. (2013), Społeczeństwo spacyfikowane, „Rzeczpospolita”, 16 V 2013, s. A10.

Vogl J. (2011), Rynek już nie jest bogiem, „Gazeta Wyborcza”, 3-4 IX 2011, s. 18.

Żyżyński J. (2013), O naprawie gospodarki, ,Rzeczpospolita”, 1 X 2013, s. A10-A11.

\section{Poverty and affluence in Poland in the early $21^{\text {st }}$ century. The assessment of neoliberalism from the perspective of Catholic social teaching}

\section{Summary}

The theory and practice of modern capitalism results in the moral and intellectual degradation of man, limits his rights, and drives him to poverty, while affluence is ac- 
cessible only to the few. The fundamental error of the system concerns the omnipotence of the market and free competition. An increasing part of society is driven to passivity. Catholic social teaching promotes a social market economy where both the social state and the people care for the common good. 